\title{
Micronutrients and Alzheimer's disease
}

\author{
Hannes B. Staehelin \\ Geriatric University Clinic, University Hospital, CH-4031 Basel, Switzerland
}

\begin{abstract}
The current high life expectancy is overshadowed by neurodegenerative illnesses that lead to dementia and dependence. Alzheimer's disease (AD) is the most common of these conditions, and is considered to be a proteinopathy, with amyloid- $\beta 42$ as a key factor, leading via a cascade of events to neurodegeneration. Major factors involved are oxidative stress, perturbed $\mathrm{Ca}$ homeostasis and impaired energy metabolism. Protection against oxidative stress by micronutrients (including secondary bioactive substances) has been shown in transgenic Alzheimer model systems to delay AD. Epidemiological evidence is less conclusive, but the vast majority of the evidence supports a protective effect on cognitive functions in old age and AD. Thus, a diet rich in fruits and vegetables but also containing meat and fish is the most suitable to provide adequate micronutrients. The strong link between cardiovascular risk and $\mathrm{AD}$ may be explained by common pathogenetic mechanisms mediated, for example, by homocysteine and thus dependant on B-vitamins (folate and vitamins $\mathrm{B}_{12}$ and $\mathrm{B}_{6}$ ). However, micronutrients may also be harmful. The high affinity of amyloid for metals ( $\mathrm{Fe}, \mathrm{Al}$ and $\mathrm{Zn})$ favours the generation of reactive oxygen species and triggers an inflammatory response. Micronutrients in a balanced diet have a long-lasting, albeit low, protective impact on brain aging, hence prevention should be life long.
\end{abstract}

Alzheimer's disease: Oxidative stress: Cognitive function

Dementia, and thus its major cause Alzheimer's disease (AD), has become one of the major health challenges of the 21 st century in industrialized societies. Prevalence studies (Jorm \& Jolley, 1998) and incidence studies (The Canadian Study of Health and Aging Working Group, 2000) consistently show a single exponential increase with age, which is consistent with involvement of a large number of complex genetic and environmental interactions. Among these factors, nutrition, intimately linked to aging, plays an important role. However, despite the strong age-related link, $\mathrm{AD}$ is not an inevitable consequence of a long life. The incidence levels at age 90 years and in centenarians indicate that many individuals in this age-group are barely affected by AD (Ritchie \& Lovestone, 2002). The present review explores the extent to which micronutrients may influence the onset of $\mathrm{AD}$ and related dementias either by preventing or delaying the disease or by fuelling the pathology.

The clinical diagnosis of $\mathrm{AD}$ is characterized by a progressive deterioration of memory, as well as other cognitive functions, and impairment of affective and emotional control, resulting in disability in daily living and loss of autonomy. Neuropathology remains the diagnostic gold standard, characterized by deposits of amyloid- $\beta$ (abeta; a fragment of the large amyloid precursor protein (APP)) in plaques and in vessel walls and aggregated tauproteins in tangles, reactive micgrogliosis and astrocytosis, leading to neuronal death with subsequent atrophy of the brain and enlargement of the ventricles. One of the first events is the loss of synapses, leading to neuronal dysfunction (Lovestone \& McLoughlin, 2002). The elucidation of the mechanism leading to the hallmarks of $\mathrm{AD}$, i.e. the loss of synapses, the formation of amyloid plaques and fibrillary tangles, should yield valuable hypotheses on how nutrients, lifestyle factors or drugs might modify this otherwise largely intrinsic process linked to aging.

The pathological cascade is apparently triggered in susceptible individuals many years before clinical symptoms emerge. Thus, environmental factors and nutrients may play an important role early in the life cycle (Fig. 1). The late onset of the disease further indicates that genetic controls diminish with advancing age and the impact of external factors becomes more prominent. However, the similar prevalence and incidence over a wide range of

\footnotetext{
Abbreviations: abeta, amyloid- $\beta$; AD, Alzheimer's disease; APP, amyloid precursor protein.

Corresponding author: Professor Hannes B. Staehelin, fax +4161 265 3788, email Hannes-B.Staehelin@unibas.ch
} 
Pathological cascade in Alzheimer's disease

\begin{tabular}{|c|c|c|}
\hline & & \\
\hline Repair capacity for DNA & Structural changes & Mutations \\
\hline Antioxidant enzymes & DNA & Chromosome 21,14,1 \\
\hline Endogenous antioxidants & Cell organelles & ApoE \\
\hline $\begin{array}{l}\text { e.g. Melatonin } \\
\text { Antioxidants }\end{array}$ & Membranes & $\begin{array}{l}\text { DNA damage } \\
\text { mDNA }\end{array}$ \\
\hline Folic acid & & Insulin-degrading enzyme \\
\hline Vitamin $B_{12}$ & & SNP not yet identified etc \\
\hline Flavonoids & Functional changes & \\
\hline Anti-inflammatory agents & Neuronal dystunction & Oxidative stress ROS \\
\hline $\begin{array}{l}\text { Non-vitamin natural } \\
\text { antioxidant polyphenols etc. }\end{array}$ & \begin{tabular}{c|c}
$\begin{array}{c}\text { Abeta } \\
+++\end{array}$ & $\begin{array}{c}\text { Tau-hyper- } \\
\text { phos } \\
+++\end{array}$ \\
Neuronal death
\end{tabular} & $\begin{array}{l}\text { Radiation } \\
\text { Metals } \\
\text { Nutrient deficiencies } \\
\text { Hyperhomocysteinaemia } \\
\text { Increased abeta }\end{array}$ \\
\hline & & $\begin{array}{l}\text { Inflammation } \\
\text { Diabetes } \\
\text { Obesity } \\
\text { Hypertension }\end{array}$ \\
\hline
\end{tabular}

Fig. 1. Structural damage leading to functional impairment and ultimately to neuronal death is influenced by many components at different levels, some of which are protective and some are damaging. Opportunities for interventions arise from preventing associated illnesses as well as by direct effects via nutrients on the cascade of pathological events such as amyloid- $\beta$; ROS, reactive oxygen species; tau-hyperphos, tau-hyperphosphorylation, SNP, single-nucleotide polymorphisms.

dietary habits and social settings in different societies, at least in the industrialized world, suggests that diet and nutritional habits may only have a small effect on the manifestation of the disease. Furthermore, the epidemiology of $\mathrm{AD}$ supports the notion that the response of the aging brain to accumulating stress of endogenous origin, such as free radicals generated during mitochondrial energy production (Turner \& Schapira, 2001; Aliev et al. 2002) and by exogenous factors, is non-specific. Thus, the question arises as to how micronutrients affect these processes. Micronutrients are essential for growth and function, and their metabolic effects were elucidated during the last century by investigating deficiency states. In this context deficiency of I, leading to goitre and cretinism, and also deficiencies of some vitamins were found to affect brain function. Subsequently, the regulatory agencies set the recommended dietary intake at a level sufficient to prevent signs and symptoms related to deficiency. There is evidence that higher intakes of certain micronutrients may be beneficial in reducing the risk of AD (Bates et al. 2002).

\section{Oxidative stress and antioxidants in Alzheimer's disease}

Oxidative stress is thought to be an early event in AD, and also to be increased by the disease process in a vicious circle. As a consequence, antioxidant defence should retard or even prevent the development of the disease. Brain metabolism requires a high and constant energy supply by mitochondria, leading to a constant load of free radical formation (Aliev et al. 2002; Engelhart et al. 2002b; Cutler et al. 2004), which suggests that a high antioxidant intake as nutrients in food and beverages might be protective (Joseph et al. 1996).

However, several mechanisms seem to interact. Thus, insulin seems to improve the energy supply to the brain and enhance brain function. However, high glucose levels and hyperinsulinaemia indicate insulin resistance and the formation of advanced glycation end products that by itself contributes to radical formation, with detrimental consequences to nerve cells and blood vessels (White, 2003). On the other hand, the defence mechanism may be directly related to nutrients, or the nutrients may exert their influence indirectly. For example, there is an increased risk of $\mathrm{AD}$ in the presence of vascular risk factors, leading to hypoxia, oxidative stress and neuronal damage (Hofman et al. 1997; Seshadri et al. 2002). Another example is folic acid, vitamin $\mathrm{B}_{12}$ and vitamin $\mathrm{B}_{6}$, which affect homocysteine metabolism and indirectly influence oxidative stress, but also protect DNA against reactive oxygen species and radiation damage by methylation (Fenech, 2001). It has been observed (Fusek, 2001) that parenteral substitution of low vitamin $\mathrm{B}_{12}$ levels $(<180 \mathrm{pmol} / \mathrm{l})$ is associated with a markedly better cognitive performance in AD-patients after 1 year, but only if the substitution occurs within 24 months after the onset of the first symptoms.

Epidemiological evidence suggests that a high intake of antioxidants in food correlates with a lower incidence of cognitive decline (Gray et al. 2003). For antioxidants nutrients, particularly vitamins $\mathrm{C}$ and $\mathrm{E}$ but also carotenoids such as lycopene, epidemiological studies (Haller et al. 1996; La Rue et al. 1997; Masaki et al. 2000) have shown correlations between intakes, plasma levels and cognitive function. On the other hand, the findings of intervention studies of the effect of antioxidants in patients with AD (Rutten et al. 2002; Gilgun-Sherki et al. 2003) have been mostly disappointing. One explanation may be that the effect of altering one antioxidant has no substantial impact on the cellular redox system, or that the intervention is too late to be of clinical significance.

Plasma antioxidant levels have been shown to predict memory performance over a 20-year period in the 


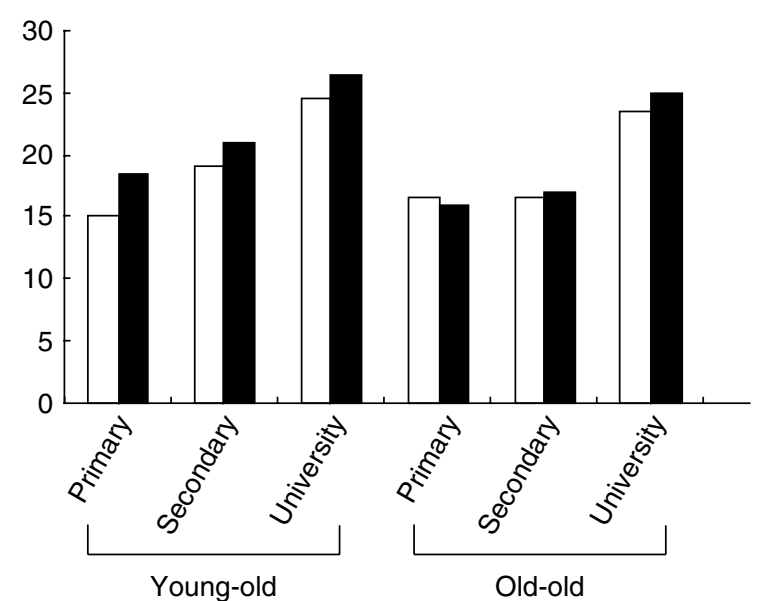

Fig. 2. Semantic memory in 380 subjects from the prospective Basel Study subdivided into young-old (65-74 years) and old-old ( $\geq 75$ years) groups with low $(\square)$ and high $(\square)$ plasma vitamin $C$ (50th percentile as a cut off), assessed from 1971 to 1973 and cognitively assessed in 1993. The effect of vitamin C on memory performance is present in all groups independent of education (From Perrig et al. 1997).

Basel Study (Perrig et al. 1997; Fig. 2) and also in the unrelated cross-sectional SENECA study (Haller et al. 1996), in which higher plasma levels were found to be associated with better memory performance. However, epidemiological surveys have provided a mixed picture. In the Rotterdam Study (Engelhart et al. 2002b) lower risk of $\mathrm{AD}$ was found to be associated with high intakes of vitamin $\mathrm{E}$ and $\mathrm{C}$, and also $\beta$-carotene and flavonoids in smokers, in a 6-year follow-up, while vitamins $\mathrm{E}$ and $\mathrm{C}$ in the diet or as supplements were found to have no effect on cognition in the Washington Heights-Inwood Columbia Aging Project 4-year follow-up (Luchsinger et al. 2002). On the other hand, the intakes of vitamin $\mathrm{C}$ and $\mathrm{E}$ supplements have been reported to be associated with lower incidence of $\mathrm{AD}$ (4.3 years follow-up; Morris et al. 1998). However, the provision of supplements remains controversial. It has been observed that vitamin E appears to be protective when derived from the diet but not when provided as a supplement, and then only in apoE $E_{4}$-negative subjects (Morris et al. 2002). However, in the Honolulu Asia Aging Study it was found that vitamin E and C supplements appear to protect against vascular dementia and improve cognitive function in later life (Masaki et al. 2000), although midlife dietary intake of antioxidants has no apparent effect on dementia in later life (Laurin et al. 2002). In the Nurses' Health Study vitamin E supplements but not vitamin $\mathrm{C}$ supplements were found to be related to modest cognitive benefits in older women (Grodstein et al. 2003), while in the Cache County Study vitamin E and C supplements in combination were reported to reduce the prevalence and incidence of AD (Zandi et al. 2004).

A widely published but controversial study relating to the mechanism of action of extremely high doses of vitamin $E(2000 \mathrm{mg} / \mathrm{d})$ in patients with $\mathrm{AD}$ suggests that such levels can lead to a delay in institutionalization (Sano
Table 1. Memory performance, as assessed by mini mental status examination, and its correlation with plasma micronutrient levels; results of the SENECA Study (Haller et al. 1996)

\begin{tabular}{lcc}
\hline Micronutrient & $r^{*}$ & $P$ \\
\hline$\alpha$-Carotene & $0 \cdot 11$ & $<0.001$ \\
$\beta$-Carotene & 0.09 & $<0.05$ \\
Lycopene & $0 \cdot 17$ & $<0.001$ \\
$\beta$-Cryptoxanthene & $0 \cdot 19$ & $<0.001$ \\
$\alpha$-Tocopherol & $0 \cdot 16$ & $<0.001$ \\
Folate & 0.10 & $<0.05$ \\
Cobalamine & 0.13 & $<0.001$
\end{tabular}

*The cross-sectional analysis of the SENECA cohort reveals significant, albeit weak, correlations between plasma antioxidant micronutrients and memory performance.

et al. 1997). The French Paquid Study has demonstrated that high flavonoid intake is associated with a reduction in risk of dementia to a relative risk of 0.49 (Commenges et al. 2000), and in the SENECA Study (Haller et al. 1996) cross-sectional analysis (Table 1) has shown a consistent and significant, albeit weak, correlation between memory performance and plasma concentrations of carotenoids, folate $(P<0 \cdot 05)$ and $\alpha$-tocopherol $(P<0 \cdot 05)$.

An important point remains that although higher vitamin $\mathrm{C}$ intake predicts better memory function, factors such as education are far more important than differences in micronutrient intakes (Perrig et al. 1997; Fig. 2). The epidemiological findings to some extent contradict the vast amount of experimental work in cell culture, and in transgenic models of AD in which bioactive antioxidant compounds show a profound effect on markers of $\mathrm{AD}$ and behaviour. Thus, numerous phenolic substances have been shown to be protective (Joseph et al. 1998a,b, 2005), probably by affecting $\mathrm{Ca}$ homeostasis in neuronal cells (Joseph et al. 2004).

\section{Metals, oxidative stress and Altzheimer's disease}

\section{Copper and zinc}

Of particular interest is the role of metals. The interaction between $\mathrm{Fe}, \mathrm{Cu}$ and $\mathrm{Zn}$, and also $\mathrm{Al}$ and other metals (e.g. $\mathrm{Hg}, \mathrm{As}$ etc.), and amyloid and the amyloid- $\beta$ (abeta) fragment of the APP molecule is complex and may depend on cholesterol metabolism (House et al. 2004; Fisher \& Naughton, 2005; Maynard et al. 2005; Valko et al. 2005). APP has $\mathrm{Cu}$-binding sites and experimental findings (Maynard et al. 2005) indicate that a high $\mathrm{Cu}$ content stabilizes APP. The function of APP is still largely unknown, but one of the possible functions might be the regulation of metal homeostasis (Fisher \& Naughton, 2005). Low $\mathrm{Cu}$ levels actually increase amyloid and abeta concentrations and high $\mathrm{Cu}$ levels stabilize APP. Increasing brain $\mathrm{Cu}$ availability decreases levels of abeta and amyloid plaque formation. Lowering $\mathrm{Cu}$ concentrations leads to a downregulation of the transcription of APP (Maynard et al. 2005).

APP is catabolized either by $\alpha$-secretase and subsequently by $\gamma$-secretase leading to non-toxic fragments or, if 
internalized in the endoplasmic reticulum and Golgi apparatus, by $\beta$-secretase and $\gamma$-secretase. The resulting abeta fragment is a key pathogenic intermediate in AD (Lovestone \& McLoughlin, 2002; Selkoe \& Schenk, 2002). Hence, APP is a large membrane-bound $\mathrm{Cu}$-binding protein that is essential in maintaining synaptic function. Both APP and abeta oxidize cholesterol, requiring $\mathrm{Cu}$. Oxycholesterol inhibits $\alpha$-secretase but not $\beta$-secretase, thus accelerating abeta production. Furthermore, oxycholesterol has a 200-fold higher affinity to abeta than to APP. Thus, at a given point $\mathrm{Cu}$ may become a powerful enhancer of reactive oxygen species formation and the APP stabilizing effect will be lost (Nelson \& Alkon, 2005).

A fascinating hypothesis emerges from experiments with transgenic animals in which a diet deficient in $n-3$ fatty acids perinatally up regulates $\mathrm{Zn}$ transport proteins in the brain that remain up regulated into adulthood, leading to a $\mathrm{Zn}$ overload in the brain and displacement of $\mathrm{Cu}$ from APP binding sites, thus favouring abeta formation (Jayasooriya et al. 2005).

\section{Iron, aluminium, selenium and mercury}

$\mathrm{Fe}$ and $\mathrm{Al}$ co-localize with abeta plaques (Exley, 2005). High cholesterol levels are thought to be a risk factor for AD (Engelhart et al. 2002a), but as a single factor they are probably of minor importance (Hofman et al. 1997); however, together with a high Fe load the risk is markedly elevated. The National Health and Nutrition Examination Survey I 18-year follow-up $(n>6500)$ has found that the risk ratio for developing $\mathrm{AD}$ is $3 \cdot 19$ (95\% CI $1 \cdot 31,7 \cdot 75)$ when both transferrin saturation and cholesterol are above the 75th percentile (Mainous et al. 2005).

Levels of advanced glycation end products and lipid peroxidation products in the brain, cerebrospinal fluid and plasma of patients with $\mathrm{AD}$ are potentiated by $\mathrm{Al}$ and $\mathrm{Fe}$ (House et al. 2004).

Al affects neuronal structures (synapses etc.; Jing et al. 2004), and chronic exposure to $\mathrm{Al}$ in drinking water increases inflammatory variables selectively in the brain (Campbell et al. 2004), while presenilin 2 production (aberrant splicing isoform, a diagnostic feature of sporadic $\mathrm{AD})$ induced by hypoxia is accelerated by chronic $\mathrm{Al}$ exposure (Matsuzaki et al. 2004).

Despite the importance of $\mathrm{Se}$ as an antioxidant and key trace element for antioxidant enzymes there is little information relating to Se and AD (Cornett et al. 1998; Meseguer et al. 1999; Tabet et al. 2001; Chen \& Berry, 2003). Of interest is the interaction between $\mathrm{Se}$ and $\mathrm{Hg}$. Uptake of $\mathrm{Hg}$ into cells may be effected by the same transport mechanisms as Se uptake (Bridges \& Zalups, 2005). Thus, in theory low Se levels in food may expose cells to higher $\mathrm{Hg}$ loads. The formation of a $\mathrm{Hg}-\mathrm{Se}$ complex seems to be protective, as is suggested by findings in marine animals (Endo et al. 2002) and in cell cultures (Frisk et al. 2003). A relationship between $\mathrm{Hg}$ exposure (e.g. by dental fillings) and AD (Fung et al. 1997) has not (Fung et al. 1997) been established, even though a correlation has been shown between $\mathrm{Hg}$ concentration and $\mathrm{Fe}$ (Barany et al. 2005) and dental fillings (Fung et al. 1997; Barany et al. 2003).

\section{Conclusions}

The uniform single exponential increase with age of dementia and $\mathrm{AD}$, with comparable rates in many socioculturally-different societies, indicate that endogenous genetic-metabolic factors are prominent. Nevertheless, micronutrients may affect the rate of disease via protection against reactive oxygen species, directly as antioxidants or indirectly by stabilizing sensitive structures or improving metabolism. The effect of pro-oxidant nutrients, on the other hand, may catalyse the development of disease by interaction with proteins and lipids involved in the pathophysiology of $\mathrm{AD}$ and other neurodegenerative disorders. Based on these premises the impact of micronutrients is most effective if present over a long period during the lifetime, while interventions later in the disease process are of minor effectiveness (Launer \& Kalmijn, 1998; Tabet et al. 2001). Of potentially far-reaching consequences is the concept that nutritional conditions in early life may programme metabolic functions, leading over time to an increasing imbalance and thus favouring the emergence of diseases states. A macronutrient and micronutrient intake that has preventive effects against CVD is most likely also to be effective against neurodegenerative disorders.

\section{References}

Aliev G, Smith MA, Seyidov D, Neal ML, Lamb BT, Nunomura A, Gasimov EK, Vinters HV, Perry G, LaManna JC \& Friedland RP (2002) The role of oxidative stress in the pathophysiology of cerebrovascular lesions in Alzheimer's disease. Brain Pathology 12, 21-35.

Barany E, Bergdahl IA, Bratteby LE, Lundh T, Samuelson G, Skerfving S \& Oskarsson A (2003) Mercury and selenium in whole blood and serum in relation to fish consumption and amalgam fillings in adolescents. Journal of Trace Elements in Medicine and Biology 17, 165-170.

Barany E, Bergdahl IA, Bratteby LE, Lundh T, Samuelson G, Skerfving S \& Oskarsson A (2005) Iron status influences trace element levels in human blood and serum. Environmental Research 98, 215-223.

Bates CJ, Benton D, Biesalski HK, Staehelin HB, van Staveren W, Stehle P, Suter PM \& Wolfram G (2002) Nutrition and aging: a consensus statement. Journal of Nutrition, Health and Aging 6, 103-116.

Bridges CC \& Zalups RK (2005) Molecular and ionic mimicry and the transport of toxic metals. Toxicology and Applied Pharmacology 204, 274-308.

Campbell A, Becaria A, Lahiri DK, Sharman K \& Bondy SC (2004) Chronic exposure to aluminium in drinking water increases inflammatory parameters selectively in the brain. Journal of Neuroscience Research 75, 565-572.

Chen J \& Berry MJ (2003) Selenium and selenoproteins in the brain and brain diseases. Journal of Neurochemistry 86, 1-12.

Commenges D, Scotet V, Renaud S, Jacqmin-Gadda H, Barberger-Gateau P \& Dartigues JF (2000) Intake of flavonoids and risk of dementia. European Journal of Epidemiology 16, 357-363.

Cornett CR, Markesbery WR \& Ehmann WD (1998) Imbalances of trace elements related to oxidative damage in Alzheimer's disease brain. Neurotoxicology 19, 339-345.

Cutler RG, Kelly J, Storie K, Pedersen WA, Tammara A, Hatanpaa K, Troncoso JC \& Mattson MP (2004) Involvement of oxidative stress-induced abnormalities in ceramide and 
cholesterol metabolism in brain aging and Alzheimer's disease. Proceedings of the National Academy of Sciences USA 101, 2070-2075.

Endo T, Haraguchi K \& Sakata M (2002) Mercury and selenium concentrations in the internal organs of toothed whales and dolphins marketed for human consumption in Japan. The Science of the Total Environment 300, 15-22.

Engelhart MJ, Geerlings MI, Ruitenberg A, van Swieten JC, Hofman A, Witteman JC \& Breteler MM (2002a) Diet and risk of dementia: Does fat matter: The Rotterdam Study. Neurology 59, 1915-1921.

Engelhart MJ, Geerlings MI, Ruitenberg A, van Swieten JC, Hofman A, Witteman JC \& Breteler MM (2002b) Dietary intake of antioxidants and risk of Alzheimer disease. Journal of the American Medical Association 287, 3223-3229.

Exley C (2005) The aluminium-amyloid cascade hypothesis and Alzheimer's disease. Sub-cellular Biochemistry 38, 225-234.

Fenech M (2001) The role of folic acid and Vitamin B12 in genomic stability of human cells. Mutation Research 475, $57-67$.

Fisher A \& Naughton D (2005) Why nutraceuticals do not prevent or treat Alzheimer's disease. Nutrition Journal 4, 14.

Frisk P, Wester K, Yaqob A \& Lindh U (2003) Selenium protection against mercury-induced apoptosis and growth inhibition in cultured K-562 cells. Biological Trace Element Research 92, 105-114.

Fung YK, Meade AG, Rack EP \& Blotcky AJ (1997) Brain mercury in neurodegenerative disorders. Journal of Toxicology 35, 49-54.

Fusek M (2001) Der subnormale Cobalaminspiegel, die Cobalaminsubstitution und die kognitiven Fähigkeiten bei Demenz (Subnormal cobalamin level, cobalamin substitution and cognitive ability in dementia). Medical Thesis, University of Basel.

Gilgun-Sherki Y, Melamed E \& Offen D (2003) Antioxidant treatment in Alzheimer's disease: current state. Journal of Molecular Neuroscience 21, 1-11.

Gray SL, Hanlon JT, Landerman LR, Artz M, Schmader KE \& Fillenbaum GG (2003) Is antioxidant use protective of cognitive function in the community-dwelling elderly? American Journal of Geriatric Pharmacotherapy 1, 3-10.

Grodstein F, Chen J \& Willett WC (2003) High-dose antioxidant supplements and cognitive function in community-dwelling elderly women. American Journal of Clinical Nutrition 77, 975-984.

Haller J, Weggemans RM, Ferry M \& Guigoz Y (1996) Mental health: minimental state examination and geriatric depression score of elderly Europeans in the SENECA study of 1993. European Journal of Clinical Nutrition 50, Suppl. 2, S112-S116.

Hofman A, Ott A, Breteler MM, Bots ML, Slooter AJ, van Harskamp F, van Duijn CN, Van Broeckhoven C \& Grobbee DE (1997) Atherosclerosis, apolipoprotein E, and prevalence of dementia and Alzheimer's disease in the Rotterdam Study. Lancet 349, 151-154.

House E, Collingwood J, Khan A, Korchazkina O, Berthon G \& Exley C (2004) Aluminium, iron, zinc and copper influence the in vitro formation of amyloid fibrils of Abeta42 in a manner which may have consequences for metal chelation therapy in Alzheimer's disease. Journal of Alzheimer's Disease 6, 291-301.

Jayasooriya AP, Ackland ML, Mathai ML, Sinclair AJ, Weisinger HS, Weisinger RS, Halver JE, Kitajka K \& Puskas LG (2005) Perinatal omega-3 polyunsaturated fatty acid supply modifies brain zinc homeostasis during adulthood. Proceedings of the National Academy of Sciences USA 102, $7133-7138$.
Jing Y, Wang Z \& Song Y (2004) Quantitative study of aluminum-induced changes in synaptic ultrastructure in rats. Synapse 52, 292-298.

Jorm AF \& Jolley D (1998) The incidence of dementia: a metaanalysis. Neurology 51, 728-733.

Joseph JA, Denisova N, Fisher D, Shukitt-Hale B, Bickford P, Prior R et al. (1998a) Membrane and receptor modifications of oxidative stress vulnerability in aging. Nutritional considerations. Annals of the New York Academy of Sciences $\mathbf{8 5 4}$ 268-276.

Joseph JA, Denisova N, Villalobos-Molina R, Erat S \& Strain J (1996) Oxidative stress and age-related neuronal deficits. Molecular and Chemical Neuropathology 28, 35-40.

Joseph JA, Fisher DR \& Carey AN (2004) Fruit extracts antagonize abeta- or DA-induced deficits in $\mathrm{Ca}^{2+}$ flux in M1-transfected COS-7 cells. Journal of Alzheimer's Disease $\mathbf{6}$, 403-411.

Joseph JA, Shukitt-Hale B \& Casadesus G (2005) Reversing the deleterious effects of aging on neuronal communication and behavior: beneficial properties of fruit polyphenolic compounds. American Journal of Clinical Nutrition 81, 313S-316S

Joseph JA, Shukitt-Hale B, Denisova NA, Bielinski D, Martin A, McEwen JJ \& Bickford PC (1998b) Long-term dietary strawberry, spinach, or vitamin $\mathrm{E}$ supplementation retards the onset of age-related neuronal signal-transduction and cognitive behavioral deficits. Journal of Neuroscience $\mathbf{1 8}$ 8047-8055.

La Rue A, Koehler KM, Wayne SJ, Chiulli SJ, Haaland KY \& Garry PJ (1997) Nutritional status and cognitive functioning in a normally aging sample: a 6-y reassessment. American Journal of Clinical Nutrition 65, 20-29.

Launer LJ \& Kalmijn S (1998) Anti-oxidants and cognitive function: a review of clinical and epidemiologic studies. Journal of Neural Transmission 53, Suppl., 1-8.

Laurin D, Foley DJ, Masaki KH, White LR \& Launer LJ (2002) Vitamin $\mathrm{E}$ and $\mathrm{C}$ supplements and risk of dementia. Journal of the American Medical Association 288, 2266-2268.

Lovestone S \& McLoughlin DM (2002) Protein aggregates and dementia: is there a common toxicity? Journal of Neurology, Neurosurgery, and Psychiatry 72, 152-161.

Luchsinger JA, Tang MX, Shea S \& Mayeux R (2002) Caloric intake and the risk of Alzheimer disease. Archives of Neurology 59, 1258-1263.

Mainous AG 3rd, Eschenbach SL, Wells BJ, Everett CJ \& Gill JM (2005) Cholesterol, transferrin saturation, and the development of dementia and Alzheimer's disease: results from an 18-year population-based cohort. Family Medicine 37, $36-42$.

Masaki KH, Losonczy KG, Izmirlian G, Foley DJ, Ross GW, Petrovitch H, Havlik R \& White LR (2000) Association of vitamin $\mathrm{E}$ and $\mathrm{C}$ supplement use with cognitive function and dementia in elderly men. Neurology 54, 1265-1272.

Matsuzaki S, Manabe T, Katayama T, Nishikawa A, Yanagita T, Okuda H, Yasuda Y, Miyata S, Meshitsuka S \& Tohyama M (2004) Metals accelerate production of the aberrant splicing isoform of the presenilin-2. Journal of Neurochemistry 88, $1345-1351$.

Maynard CJ, Bush AI, Masters CL, Cappai R \& Li QX (2005) Metals and amyloid-beta in Alzheimer's disease. International Journal of Experimental Pathology 86, 147-159.

Meseguer I, Molina JA, Jimenez-Jimenez FJ, Aguilar MV, Mateos-Vega CJ, Gonzalez-Munoz MJ et al. (1999) Cerebrospinal fluid levels of selenium in patients with Alzheimer's disease. Journal of Neural Transmission 106, 309-315.

Morris MC, Beckett LA, Scherr PA, Hebert LE, Bennett DA, Field TS \& Evans DA (1998) Vitamin E and vitamin C 
supplement use and risk of incident Alzheimer disease. Alzheimer Disease and Associated Disorders 12, 121-126.

Morris MC, Evans DA, Bienias JL, Tangney CC, Bennett DA, Aggarwal N, Wilson RS \& Scherr PA (2002) Dietary intake of antioxidant nutrients and the risk of incident Alzheimer disease in a biracial community study. Journal of the American Medical Association 287, 3230-3237.

Nelson TJ \& Alkon DL (2005) Oxidation of cholesterol by amyloid precursor protein and beta-amyloid peptide. Journal of Biological Chemistry 280, 7377-7387.

Perrig WJ, Perrig P \& Stahelin HB (1997) The relation between antioxidants and memory performance in the old and very old. Journal of the American Geriatrics Society 45, 718-724.

Ritchie K \& Lovestone S (2002) The dementias. Lancet 360, $1759-1766$.

Rutten BP, Steinbusch HW, Korr H \& Schmitz C (2002) Antioxidants and Alzheimer's disease: from bench to bedside (and back again). Current Opinion in Clinical Nutrition and Metabolic Care 5, 645-651.

Sano M, Ernesto C, Thomas RG, Klauber MR, Schafer K, Grundman M et al. (1997) A controlled trial of selegiline, alpha-tocopherol, or both as treatment for Alzheimer's disease. The Alzheimer's Disease Cooperative Study. New England Journal of Medicine 336, 1216-1222.
Selkoe DJ \& Schenk D (2002) Alzheimer's disease: molecular understanding predicts amyloid-based therapeutics. Annиal Review of Pharmacology and Toxicology 4, 4.

Seshadri S, Beiser A, Selhub J, Jacques PF, Rosenberg IH, D'Agostino RB, Wilson PW \& Wolf PA (2002) Plasma homocysteine as a risk factor for dementia and Alzheimer's disease. New England Journal of Medicine 346, 476-483.

Tabet N, Mantle D, Walker Z \& Orrell M (2001) Vitamins, trace elements, and antioxidant status in dementia disorders. International Psychogeriatrics 13, 265-275.

The Canadian Study of Health and Aging Working Group (2000) The incidence of dementia in Canada. The Canadian Study of Health and Aging Working Group. Neurology 55, 66-73.

Turner C \& Schapira AH (2001) Mitochondrial dysfunction in neurodegenerative disorders and ageing. Advances in Experimental Medicine and Biology 487, 229-251.

Valko M, Morris H \& Cronin MT (2005) Metals, toxicity and oxidative stress. Current Medicinal Chemistry 12, 1161-1208.

White MF (2003) Insulin signaling in health and disease. Science 302, 1710-1711.

Zandi PP, Anthony JC, Khachaturian AS, Stone SV, Gustafson D, Tschanz JT, Norton MC, Welsh-Bohmer KA \& Breitner JC (2004) Reduced risk of Alzheimer disease in users of antioxidant vitamin supplements: the Cache County Study. Archives of Neurology 61, 82-88. 